\title{
The Development of Library Use Instructional Programs
}

\begin{abstract}
Considerable duplication of effort exists in library use instructional development. Much duplication could be eliminated and universality increased, if instruction were formulated under basic instructional psychology principles. The development of instructional programs at Brigham Young University Clark Library indicates how instructional psychology techniques can provide valid and effective instruction with guaranteed high levels of learning. Each program defines the behavioral objectives and matches these objectives with test questions. Then instruction consistent with the test and the behavioral objectives is written. Finally each program is statistically validated. Average learning from such programs has increased from the thirtieth to the eightieth percentiles.
\end{abstract}

E VERY DAY PATRONS WALK OUT of our libraries convinced that there is little or nothing in our collections on their topics of study. Of course, frequently there is a great amount of information; the patron simply doesn't know how to find it and is often too timid to ask for help. During the summer of 1970, the Brigham Young University library launched a new program in an attempt to solve this problem-to teach its entire student body basic library skills.

Dissatisfied with the usual approaches to library instruction, the library decided to call on the expertise within its own university community in formulating several effectively designed instructional packages which could be statistically validated.

A team of librarians, English instructors, educational psychologists, and non-

Marvin E. Wiggins is coordinator of reference services, Brigham Young University library, Provo, Utah. print media specialists combined efforts to design five library instructional programs that would meet the needs of all lower division students of the university. Inasmuch as sophomore English programs were already teaching basic bibliographical techniques and were reaching a majority of the students, the English composition department was asked to be a key contributor to the content of a basic library instruction package.

Several philosophical criteria were agreed upon:

First, all instruction would be designed to meet the immediate needs of the student at the grade level for which it was to be administered.

Second, no attempt would be made to teach everything a student would ever need to know throughout his entire college career in any one concentrated effort. This meant that basic information would be dealt with at the lower division level and specialized instruction in specific disciplines would be reserved 
for upper division and graduate levels of study.

Third, only a brief orientation would be given to freshman students. For motivational reasons, actual instruction in the use of library facilities would be given at the sophomore levels of the curriculum. This would better meet BYU research needs beginning at this stage of the students' program.

Fourth, instructional efforts would be planned to meet the needs of upper division and graduate students but efforts would begin at the lower levels in order to build a foundation for such instruction.

Fifth, all instruction would be provided as much as possible within the library building itself.

Sixth, all instruction would be supplemented with actual assignments. Students would be tested within the library and tests would be computer graded and routed to their instructors for evaluation purposes.

Finally, in order to provide high motivation in learning, a high level of success would be built in. Students must feel the time they spend is worthwhile. ${ }^{1}$

The focus of the effort was on five instructional programs: (1) a taped tour of the library, (2) use of the card catalog, (3) use of basic periodical indexes, (4) use of basic indexes to bibliographies, book reviews, essays, and newspapers, and (5) general use of current U.S. government documents.

Four of the five programs are now in operation, with the remaining one expected to be completed by January $1973 .{ }^{2}$ Because of the simplicity of the taped tour concept, the program will be dealt with briefly in this paper. The card catalog program is much more involved with instructional techniques and has become a model for the next three programs now in various stages of development. For this reason, the second program will be discussed in more detail.
In order to assist students in locating physical facilities and basic services, a forty minute walking cassette tape tour was designed to be given to all BYU freshmen. The tour would be a requirement of the freshman English curriculum.

Criteria were defined to establish what the student should be able to do as a result of taking the tour. Alternative methods of instruction were examined, such as physical tours given by librarians, slide-tape and videotape presentations, and cassette tapes with hand carried playback units. The cassette taped tour was adopted for four reasons:

First, a taped tour can be an effective, yet inexpensive, way to introduce 4,000 or more students a year to a large library complex. Students simply check out a cassette tape player and the information on the tape will do the rest. Slide-tape and videotape presentations are best for showing fixed locations but present a difficulty in linking one location to another.

Second, cassette players can be obtained for less than $\$ 20$. Students may come at their own convenience throughout the day and large numbers of students can be handled throughout a semester without much notice of their presence.

Third, cassette tapes can be easily and quickly updated by either splicing or making a new master. Videotapes are expensive to produce, particularly if the final project is to have a professional polish, and are often out-of-date before production is completed.

Fourth, minimal personnel are needed for distributing and repairing cassette player units.

The dean of electronic media was called in to assist in the development of the cassette tour, at which point the content of the tour was agreed upon. The length was held to twenty minutes of recorded time (forty minutes of walk- 
ing time) to hold the interest of the student. An actual tour was recorded from which a script was written. The script was scrutinized by seven subject librarians, several English instructors, a sample of freshman students, foreign students, and strangers to the university.

A computer-graded test was designed to be administered as a pre- and/or posttest, as well as to provide a reinforcement of learning, supply feedback to instructors of students taking the tour, and to supply statistical data for continual revision and updating.

The exam was given to 100 students from five freshman classes as both a pretest and posttest. Pretest scores showed that freshman students could locate just under 30 percent of the services and facilities determined to be of importance. After the tour, the figure increased to 80 percent. Except for periodic evaluation, students normally take only the posttest.

The tour has been in full use since September 1970 and has been received enthusiastically by both faculty and students. Departments other than English have also required the tour, including our Graduate Department of Library Science, senior classes in French and zoology, guided studies courses, and business education. Use by other departments will diminish each year since upcoming juniors and seniors will have already taken the tour during their freshman year.

As mentioned earlier, the card catalog program deals with a higher degree of learning and a greater sophistication in development. The card catalog program drew from the expertise of the university's Department of Instructional Research and Development, a graduate educational psychology curriculum concerned with the development of instructional programs. ${ }^{3}$

Six terminal objectives were devised utilizing six areas of card catalog use: (1) filing rules, (2) call numbers, (3) cross references, (4) author, title, and subject cards, (5) tracings, and (6) use of the Library of Congress subject headings catalog.

A terminal objective tells what kind of behavior the student should be expected to display as a result of instruction. A terminal objective on the use of tracings would be, for example, if a student were given a subject for examination in the card catalog, he would be expected to determine additional related subject headings to books of specific interest and then use those subject headings in an expanded search of his topic.

Enabling objectives are necessary to define the means of development and realization of terminal objectives. The terminal objective on tracings utilized three enabling objectives. The student should be able to (1) provide a definition of the term "tracings" as used on card catalog cards, (2) explain where the tracings are on the card, and (3) understand that tracings can be used to (a) determine the type of information found in the book, (b) know what subjects and added entries have been assigned to the book, and (c) tell what additional subject headings could be consulted for information related to a particular book.

Each of the six terminal objectives was written in similar detail with their enabling objectives. Whenever an enabling or terminal objective was written, a test question was formulated that could measure the objective. All such questions were compiled into an exam which was administered to four skilled and four unskilled subjects. The test was called a "task analysis" and its purpose was to verify the hierachial arrangement or level of difficulty and the desirable order for presentation of the objectives. It would also determine the ability of the expert and the nonexpert to perform the behavioral objectives.

Reference and cataloging librarians served as the skilled group and sopho- 
more students served as the unskilled group. The librarians scored 98 percent correct on the test in forty-eight minutes while the students answered only 32 percent correct in two and one half hours. Students were required to terminate their test after two and one half hours. The task analysis confirmed the selection of objectives and their arrangement in a logical hierarchy.

The next step was to finalize the preand posttest items as a result of the task analysis. The instructional package was then formulated to be consistent with the tests and behavioral objectives supported by the test.

A modified programmed instructional approach was adopted by which each enabling and terminal objective would be taught. Instruction was placed on tapes which were accompanied by a workbook. The concept for each enabling objective was explained and illustrated, followed by a question calling for a student response. A delay in the tape permitted sufficient time to lapse for making a response. After the delay, the correct answer was given with an explanatory note. In most cases, repetition tied the concepts together until the terminal objective was understood.

To illustrate the procedure, an example on tracings is given in Figure 1 from a later printed version of the program. Previous to the information illustrated (Figure 1), the student was taught where the tracings were located on the card. The example demonstrates how he is instructed as to the usefulness of tracings in research.

An attempt was made throughout the program to use examples the student would encounter in his own use of the card catalog. This was so that the learning situation would be real, self-motivating, and a positive experience.

Six tapes were produced, one for each section, corresponding to the six terminal objectives to be learned. The pretest was organized into the same six sections.
This way a student could take the pretest, score his own test, and determine which of the sections he needed to study and in what detail. Should the student need detailed tapes for all six objectives, he would need to allot one hour and thirty minutes for his self-instruction. The student could ask for any or all six, thus permitting him to take his instruction in more than one sitting.

Should a student know most of the information in a section, a second alternative was established. A nonprogrammed summary of rules was listed in the back of the workbook by which he could quickly pick up the few details missed on the pretest.

The pretest was designed to take the student to the library card catalog and require him to look up the information and respond to a correct multiple choice alternative.

The final step in the instructional development was to validate the program so that there would be assurance that the instruction was effective in teaching the intended information. Inasmuch as students signed up for English composition courses by section number, and most sections were listed as being taught by "staff," it was felt that a random sample was easily available by taking 161 sophomore English students from three sections. Students were offered the incentive of extra credit for participating in the experiment.

The students were randomly divided into three groups: (1) Group I (seventy-three students), receiving the taped programmed instruction; (2) Group II (fifty-one students), receiving the nonprogrammed written summation of rules; and (3) Group III (fifty students), serving as a control group and receiving no instruction.

All groups were given the same pretest in their respective classrooms. The pretest was designed to be a fixed location test that could be taken anywhere. Students in Groups I and II decided 
Predigtmärlein der Barockzeit; Exempel, Sage, Schwank und Fabel in geistlichen Quellen des oberdeutschen Raumes, Berlin, De Gruyter, 1964.

xvi, 544 p. $25 \mathrm{~cm}$. (Supplement-Serie zu Fabula; Zeitschrift für Erzahlforschung. Reihe A: Texte, Bd. 5 )

Bibliography: p. [514]-533.

1. Sermons, German-Hist. \& crit. 2. Catholic Church-SermonsHist. \& crit. 3. Homiletical illustrations-Hist. \& crit. I. Title. (Series: Fabula, Supplement Serie. Reihe A: Texte, Bd. 5)

\section{BV4208.G3M6}

$64-57943$

Library of Congress [1]

FIG. 4

\begin{tabular}{|c|c|c|}
\hline 280.1 & \multicolumn{2}{|c|}{ Local church councils. } \\
\hline Sa56c & \multicolumn{2}{|c|}{$\begin{array}{l}\text { Sanderson, Ross Warren, 1884- } \\
\text { Church cooperation in the United States; the nation-wide } \\
\text { backgrounds and ecumenical significance of state and local } \\
\text { councils of churches in their historical perspective. [New } \\
\text { York] Association of Council Secretaries, } 1960 \text {. }\end{array}$} \\
\hline & \multicolumn{2}{|l|}{272 p. $25 \mathrm{~cm}}$. \\
\hline & \multicolumn{2}{|c|}{ Includes bibliography. } \\
\hline & \multicolumn{2}{|c|}{$\begin{array}{l}\text { 1. Local church councils. 2. Interdenominational cooperation. } \\
\text { 3. Christian union-Hist. I. Title. }\end{array}$} \\
\hline & BV626.S3 & $60-13189$ \\
\hline & Library of Congress & [61f3] \\
\hline
\end{tabular}

FIG. 5
Question 4

Look at figure 4 and decide

how many subject headings

are suggested by the tracings.

Let us now see how the tracings could be of help to you in a research project. Suppose you wanted to do a paper on the subject "Local Church Councils." You would first look up that heading in the card catalog and you might find only one card - indicating only one book on this subject. The card you would find is illustrated in figure 5 . The title of the book listed on the card is Church Cooperation in the United States. If you didn't know how to use the tracings, you would be limited to this one book to use in your research.

\section{Question 5}

If you were to look up the other two subject headings in the card catalog, you might find that "interdenominational cooperation" has six books under its heading and that "Christian union history" has an additional eleven books under its heading. This would make a total of seventeen books from which
With your knowledge of trac.

ings, the listing on the card in

figure 5 refers you to how

many other subject headings?

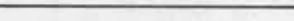

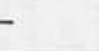
you could choose to do research.

Answer 5

Two additional subject headings. Number 1 of the arabic numerals is Local church councils, and that is the heading for this card. 
from their own pretest results which sections of instruction they should take, knowing they would be tested again on the amount of learning they had achieved. Group I took the taped programmed instruction and Group II received the nonprogrammed summation of rules. Groups I and II were again given the pretest (PAI). All groups then took the posttest. Again, the pretest is a fixed location test. However, the posttest was designed to give the student experience with the card catalog itself. Time was limited to one hour on the posttest on the presumption that if a student were given all the time he desired he could find most anything. The one-hour maximum was ten minutes longer than the skilled librarians took on the task analysis test, a test of similar composition and length. The unskilled students in the task analysis had been cut off after two and one half hours. Therefore, a student could complete the entire program in one hour and thirty minutes for instruction and one hour for the posttest.

\section{Statistical Analysis}

A summary of the results are given below in Table 1 .

An analysis of convariance using PBI as a covariate and the Scheffe and Least Significance Differences test showed significant differences between experimental and control groups (18.6

TABLE $1^{5}$

\begin{tabular}{lcccc}
\multicolumn{5}{c}{ MEAN ScoRes } \\
\hline \hline & $\begin{array}{c}\text { PBI } \\
\mathrm{n}=73\end{array}$ & $\begin{array}{c}\text { Instruction } \\
\text { yes/no }\end{array}$ & $\begin{array}{c}\text { PAI } \\
\mathbf{n}=51\end{array}$ & $\begin{array}{c}\text { PT } \\
\mathrm{n}=50\end{array}$ \\
\hline Group I & 9.8 & yes & 22.4 & 21.5 \\
Group II & 9.5 & yes & 19.2 & 18.6 \\
Group III & 9.0 & no & no & 12.7 \\
\hline
\end{tabular}

PBI -pretest before instruction (29 questions) PAI -pretest after instruction (29 questions)

PT -posttest after instruction (26 questions)

Group I -receiving taped programmed instruction

Group II -receiving nonprogrammed summation of

Group III-control group receiving no instruction and 12.7) and between the two experimental groups (21.5 and 18.6) both at less than the .01 level of significance. Groups I and II showed the same level of significance for the mean gain scores between PBI and the posttest, 11.7 and 9.1 respectively. This was an increase from 32 percent to 84 percent for Group I and from 32 percent to 72 percent for Group II. The gain of the control group from the PBI to the posttest (9.0 to 12.7) was nonsignificant. ${ }^{6}$

\section{IMPLICATIONS}

Significant differences between the control and experimental groups indicate the possibility of designing effective instructional packages for learning to use the card catalog and possibly other kinds of library systems. Differences between the programmed and nonprogrammed forms of instruction employed in this study indicate a slight but important improvement in favor of programmed instruction. Finally, the total scores of the second pretest given after instruction (a fixed location test) and the posttest (a test requiring the student to perform by looking up the answers in a card catalog) suggest the effectiveness of publishing the entire program in a print rather than tape format utilizing a fixed location test. This would permit other institutions to draw effectively upon our experience without rewriting the program to fit their individual library card catalog.

In order to take advantage of the latter finding, the taped programmed instruction was redesigned into a standard but printed programmed text format and published. It utilizes a fixed location and self-scored pre- and posttest. Students determine from their pretest scores which of the six sections or chapters they need to study in detail. At the end of each chapter there is a one-page summary of rules corresponding to the alternative offered Group II in the study. Students may then choose either, 
depending upon how well they perform on the pretest. The summary also provides an easy review of the information covered in each chapter for learning reinforcement and for final preparation before taking the final test. The entire program ends with a fixed location posttest similar to the pretest, which can be graded by the student.

Brigham Young University still makes use of the posttest requiring the students to go to the card catalog. It is felt that there is not only an advantage with slight improvement in performance, but that there is a motivational reward in actually using the card catalog. It also permits us to computer grade the tests for continual evaluation and for routing of learning results to the student's instructor. The instructor is thus freed from having to devise a test for student evaluation purposes. ${ }^{7}$

Such satisfactory results have been obtained on the card catalog program that future instructional programs (periodical indexes, indexes to bibliography, and book review essays and newspapers, and current U.S. Government documents) will follow the same or similar procedure and printed format.

\section{SUMMARY}

The study's most valuable finding is a determination of the feasibility of developing basic library use instruction that can be shown statistically to provide significant learning and at the same time meet the needs of a large number of libraries. The card catalog program in question can best be adopted by those institutions using the Dewey classification and either LC or Sears subject headings. However, the instruction could also be easily adapted to libraries which use LC or a mix of the LC and Dewey classification systems.

The amount of literature on library use instruction is so staggering that a constant concern to the author is how effective such programs may be and how they could be used elsewhere, thus avoiding the vast duplication of each other's work. If such programs can be developed scientifically, the evidence of widespread usability would be more easily accepted and adopted.

\section{REFERENCES}

1. The author is indebted to Millicent Palmer, Library Instruction Librarian, Southern Illinois University library at Edwardsville, Illinois, for her theoretical influence on the BYU program.

2. The first two programs are available for dissemination from J. Reuben Clark Jr. Library, Brigham Young University, Provo, UT 84601 . The remaining three programs are awaiting publication.

3. The author is indebted to Charles Bradshaw, a graduate assistant at BYU, for his assistance in devising and testing the behavioral objectives, designing the instructional package, and statistically validating the program. The author is also indebted to Dr. R. Irwin Goodman, director of the Brigham Young University Instructional Development Program who, in conjunction with Dr. M. David
Merrill, chairman of the BYU Department of Research and Development, devised the philosophical model for which this program was developed.

4. Reprinted from Charles I. Bradshaw with Marvin E. Wiggins and Blaine Hall, Using the Library: The Card Catalog. (Provo, Utah: Brigham Young University Press, 1971), p. $78-80$.

5. Unpublished data provided by Charles I. Bradshaw.

6. Ibid.

7. Institutions desiring a copy of our departmental posttest for developing a similar one to use with their card catalog can obtain one from the General Reference Office, J. Reuben Clark Jr. Library, Brigham Young University, Provo, UT 84601, for \$.50. 